\title{
Експериментальні дослідження деформаційних характеристик закладальних масивів
}

\begin{abstract}
Мета роботи - визначити деформаційні характеристики закладальних масивів, щчо використовуються для підтримання бічних порід позаду очисного вибою на виїмковій дільниці вугільної шахти. Для досягнення поставленої мети було виконано лабораторні дослідження на зразках із дробленої породи різного гранулометричного складу, які піддавалися одновісному стисненню в сталевому циліндрі (компресійний стиск) і в тканинній оболонці (з можливістю бічного розширення закладального матеріалу).

В результаті виконаних експериментальних досліджень встановлено характерні особливості деформування закладального масиву із дробленої породи під час компресійного стиснення, а також в умовах, коли можливе бічне розширення закладального матеріалу. Показано, що за можливості бічного розширення закладального матеріалу відносна деформація зв'язана лінійною обернено пропориійною залежністю з величиною насипної щуільності роздробленої породи. Для дробленої породи неоднорідного гранулометричного складу, під час компресійного стиснення $i$ за максимальних значень коефіцієнта ущільнення, вертикальний розмір ущільнюваного тіла на $36 \%$ менше, ніж у разі одновісного стиснення закладального матеріалу з можливістю бічного розширення подрібненої породи. Причому, чим менша фракція дробленої породи, тим більша різниця, яка спостерігається під час випробувань. За компресійного стиснення зміна обсягу ущільнюваного тіла відбувається в результаті перепакування частинок різного розміру в загальному обсязі закладального матеріалу, під час стиснення з можливістю бічного розширення, переважно за рахунок горизонтальних деформачій.

Величина коефіцієнта Пуассона в умовах одновісного стиснення дробленої породи 3 можливістю бічного розширення ущільнюваного тіла змінюється за квадратичною залежністю і досягає мінімальних значень за наявності в закладальних матеріалах неоднорідної (за розмірами частинок) дробленої породи. Максимальні значення забезпечуються після стиснення вихідного матеріалу великої або дрібної фракиій, які напочатку складають закладальний масив.

Забезпечення стійкості бічних порід, експлуатаційного стану гірничих виробок на виїмкових дільнииях вугільної шахти і запобігання осіданню земної поверхні досягається після зведення у виробленому просторі закладального масиву, щя складається з неоднорідних (за розмірами) шматків дробленої породи в умовах, відповідних компресійному стисненню. Тому вимоги до властивостей закладальних масивів $і$ способу закладки слід встановлювати відповідно до їх призначення.
\end{abstract}

Ключові слова: закладальний масив; дроблена порода; гранулометричний склад; жорсткість; насипна щзільність.

Вступ. Досвід роботи вугільних шахт показує, що зі зростанням глибини гірничих робіт все більшою мірою на стані вуглепородного масиву, що вміщає виробки, позначається розшарування породної товщі. Цей негативний природний фактор суттєво впливає на поведінку покрівлі і підошви пласта позаду очисного вибою. Особливо це простежується під час відпрацювання крутих вугільних пластів, коли обвалення розшарованої породної товщі призводять до завалу гірничих виробок і можливого травмування гірників.

Ефективність відпрацювання вугільних пластів і безпека ведення гірничих робіт у таких умовах значною мірою залежать від застосовуваного способу управління покрівлею в очисному вибої. Як показує світовий досвід відпрацювання вугільних пластів, в складних умовах великих глибин найбільш сприятливо на стан бічних порід і збереження гірничих виробок у масиві осадових гірничих порід впливає спосіб управління покрівлею закладки виробленого простору. Отже, для уникнення аварійних ситуацій i зменшення ймовірності негативних проявів гірничого тиску у виробках під час відпрацювання вугільних пластів на великих глибинах слід орієнтуватися на закладку виробленого простору. Застосування закладки виробленого простору подрібненою породою дозволить поліпшити стан бічних порід і уникнути завалів гірничих виробок. 
Аналіз літературних джерел і постановка проблеми. Сьогодні на більшості вугільних шахт, що розробляють вугільні пласти крутого падіння, для управління гірничим тиском в очисному вибої використовують спосіб утримання покрівлі на кострах або повне обвалення покрівлі. В [1] зауважується, що за утримання покрівлі на кострах забезпечується стійкість бічних порід та експлуатаційний стан дільничних підготовчих виробок. Водночас під час застосування цього способу не завжди гарантується стала і безпечна робота очисних вибоїв. Пов'язано це насамперед з утворенням незавалених площ покрівлі у виробленому просторі. Негативні наслідки такої геомеханічної обстановки можуть проявлятися за підтримки відкатних штреків. Крім того, розглянутий спосіб управління покрівлею характеризується високою трудомісткістю робіт, значною витратою кріпильних матеріалів, що обмежує поліпшення техніко-економічних показників роботи виїмкових дільниць.

Низка дослідників, зокрема у [2], розглядаючи повне обвалення покрівлі як спосіб управління гірничим тиском, рекомендує його застосування за умови легкозруйновних бічних порід. У цьому випадку, як зазначають дослідники, забезпечується стійкість гірничих виробок на виїмковій ділянці. Однак за поверхового способу підготовки крутих вугільних пластів і наявності легкозруйновних бічних порід, в результаті зміни стійкості та міцності порід по висоті поверху і в напрямку простягання пласта покрівля або підошва розбивається на блоки і неконтрольовано обвалюється. Такий стан призводить до завалу очисного вибою і відкатного штреку.

У $[3,4]$ вказується, що найбільш сприятливо на стан бічних порід у вуглепородному масиві впливає спосіб управління покрівлею закладки виробленого простору дробленою породою. Зауважується, що за використання цього способу можна уникнути обвалення бічних порід в очисному вибою в межах виїмкової дільниці. Застосування закладки виробленого простору для охорони виробок дозволить обмежити зміщення порід на контурі відкатного штреку і запобігти завалам виробок. Однак для вирішення цих питань необхідно враховувати деформаційні характеристики закладальних масивів, зокрема зміну їх жорсткості.

Світовий досвід використання закладки виробленого простору для охорони гірничих виробок i поверхневих об'єктів вказує на те, що зміна геометрії закладального масиву істотно впливає на його стисливість і характер переміщень розшарованої товщі в масиві порід. У бутовій смузі, використовуваній для охорони штреків, закладальний матеріал працює в умовах, близьких до одновісного стиснення, а в суцільному масиві, коли застосовується метод управління покрівлею закладки виробленого простору, в умовах об'ємного навантаження [5].

Очевидним є те, що стиснення закладального масиву під дією навантаження, що формується осіданням верхніх шарів, яке відбувається на деякій площі, здійснюється або в умовах можливого бічного розширення, або компресії (під компресією будемо розуміти ущільнення закладального матеріалу під впливом зовнішнього навантаження без можливості бічного розширення). За умови такої поведінки закладальних масивів виявляються їх різні деформаційні властивості. Різниця деформаційних властивостей охоронних споруд під час дії навантажень може істотно впливати на стійкість бічних порід та гірничих виробок в анізотропному вуглепородному масиві.

Постановка завдання дослідження. Визначити деформаційні характеристики закладального матеріалу із дробленої породи, який використовується для підтримання покрівлі і підошви вугільного пласта в анізотропному вуглепородному масиві позаду очисного вибою, що дозволить обгрунтувати збереження гірничих виробок і підвищити безпеку робіт у глибоких шахтах.

Методи і матеріали дослідження деформаційних характеристик закладальних масивів. Закладальний масив складається з вихідного матеріалу - роздробленої породи різних розмірів. Дуже рідко такі масиви являють собою скупчення якої-небудь однієї фракції. Зазвичай в тих чи інших співвідношеннях $є$ кілька характерних фракцій, а отже, властивості закладального масиву залежать від гранулометричного складу. Для дослідження фізико-механічних властивостей закладальних масивів у цій роботі проводився аналіз гранулометричного складу закладального матеріалу із дробленої породи. При цьому використовувався матеріал з крупністю, що відповідає прийнятому в проведених дослідженнях масштабу (відношення модельних розмірів до натурних 1:25).

Найбільш простим способом визначення гранулометричного складу $є$ просіювання вихідного матеріалу через набір стандартних сит з отворами 5-1 і 0,1 мм [6]. Для визначення у вихідному матеріалі процентного вмісту отриманих після просіювання фракцій роздробленої породи було виконано зважування на технічних вагах з точністю до 0,01 г. Сума мас всіх фракцій відрізнялася від початкової маси вихідного матеріалу на 1 \%, що відповідає вимогам методики [7]. Дані експериментальних досліджень з визначення гранулометричного складу роздробленої породи вказано в таблиці 1.

Гранулометричний склад роздробленої породи (рис. 1) охарактеризуємо коефіцієнтом неоднорідності $k_{H}$, який відображає розкид форми і розмірів дробленої породи щодо середнього їх значення. Визначивши діаметри частинок, встановимо значення коефіцієнта $k_{H}$, як це рекомендується у [8]. Встановлене у результаті експериментальних досліджень значення $k_{t}=d_{60} / d_{p}=4,8$ характеризує неоднорідність вихідного матеріалу роздробленої породи. 
Дані лабораторних досліджень гранулометричного складу роздробленої породи за допомогою ситового аналізу

\begin{tabular}{|c|c|c|}
\hline Отвір сита, мм & Розмір фракції, мм & Зміст в загальному обсязі, \% \\
\hline 5 & $>5$ & 4 \\
\hline 4 & $4-5$ & 16 \\
\hline 3 & $3-4$ & 19 \\
\hline 2 & $2-3$ & 24 \\
\hline 1 & $1-2$ & 18 \\
\hline 0,1 & $0,1-1$ & 14 \\
\hline & $<0,1$ & 5 \\
\hline
\end{tabular}

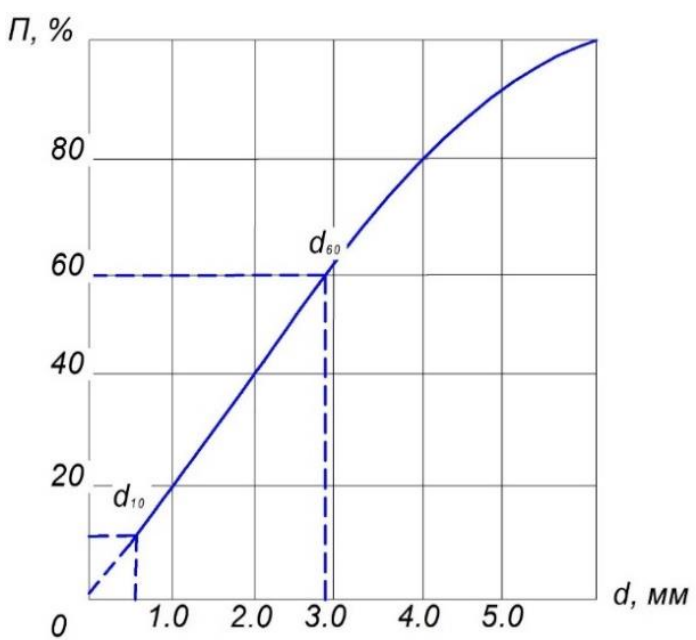

Рис. 1. Гранулометричний склад роздробленої породи як кумулятивної кривої крупності:

$d_{60}$ - контролюючий діаметр частинок, менше якого в иій породі $60 \%$ від усіх частинок;

$d_{10}$ - діючий діаметр частинок, відносно якого в цій породі $10 \%$ частинок мають менший діаметр

Фізико-механічні властивості закладальних масивів залежать від співвідношення в них основних фракцій відповідно до розглянутих особливостей кожної фракції дробленої породи. Оцінка кожного конкретного різновиду закладальних масивів як фізичного тіла проводилася авторами з використанням таких фізичних характеристик, як насипна щільність $\rho_{\text {н.n. }}\left(\right.$ кг $\left./ \mathrm{M}^{3}\right)$, жорсткість $C$ (Н/м), коефіцієнт ущільнення $k_{y m}$ і об’ємна усадка $\Delta Z(\%)$ закладального матеріалу.

Відомо [9], що насипна щільність дробленої породи $\rho_{н}\left(\kappa г / \mathrm{m}^{3}\right)$ - це маса одиниці об'єму пухкої породної маси. Під час проведення експериментів величину $\rho_{н}$ визначали з використанням спеціальної мірної посудини об'ємом $V_{c}=10^{-3} \mathrm{~m}^{3}$ і масою $m_{c}$ (кг) відповідно до методики, викладеної у [8].

Після виконання дослідів величину насипної маси $\rho_{н}\left(\kappa г / \mathrm{M}^{3}\right)$ встановлювали за формулою:

$$
\rho_{H}=\frac{m_{\Pi}-m_{c}}{V_{c}}
$$

де $m_{\Pi}$ - маса мірної посудини з дробленою породою, кг.

Вважається [10], що величина насипної щільності залежить від вологості породи і їі об'ємної ваги. Тому для випробувань використовували лабораторні проби, висушені до постійної маси.

У таблиці 2 наведено значення $\rho_{н}\left(\kappa \Gamma / \mathrm{M}^{3}\right)$ для роздробленої породи експериментальних зразків, просіяної за фракціями. Пустотність $M(\%)$ закладального матеріалу визначалася розрахунковим шляхом

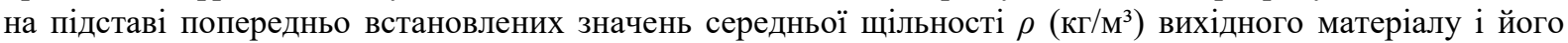
насипної щільності $\rho_{н}\left(\kappa г / \mathbf{M}^{3}\right)$ за виразом 3 [8]:

$$
M=\left(1-\frac{\rho_{H}}{\rho}\right) \cdot 100 .
$$

Дані лабораторних досліджень з визначення величини пустотності зазначено в таблиці 2. Вони свідчать, що зі збільшенням насипної щільності $\rho_{н}$ значення пустотності $M$ зменшуються.

Під час проведення дослідів як випробувальне обладнання використовувався гідравлічний прес П-50 (рис. 2). На цьому пресі експериментальні зразки піддавалися статичному навантаженню (під час їх випробування на стиснення). Максимальне зусилля, що розвивається пресом, становить 50 т. 


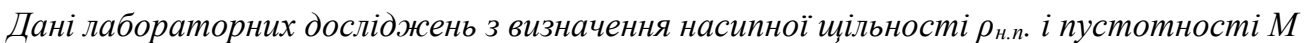
закладального матеріалу із дробленої породи

\begin{tabular}{|c|c|c|}
\hline Розмір фракції, мм & Насипна щільність $\rho_{H}, \mathrm{кг} / \mathrm{M}^{3}$ & Пустотність $M, \%$ \\
\hline $0,1-5$ & 1820 & 14 \\
\hline $4-5$ & 1680 & 20 \\
\hline $3-4$ & 1720 & 19 \\
\hline $2-3$ & 1860 & 12 \\
\hline $1-2$ & 1880 & 11 \\
\hline $1-0,1$ & 1940 & 8 \\
\hline
\end{tabular}

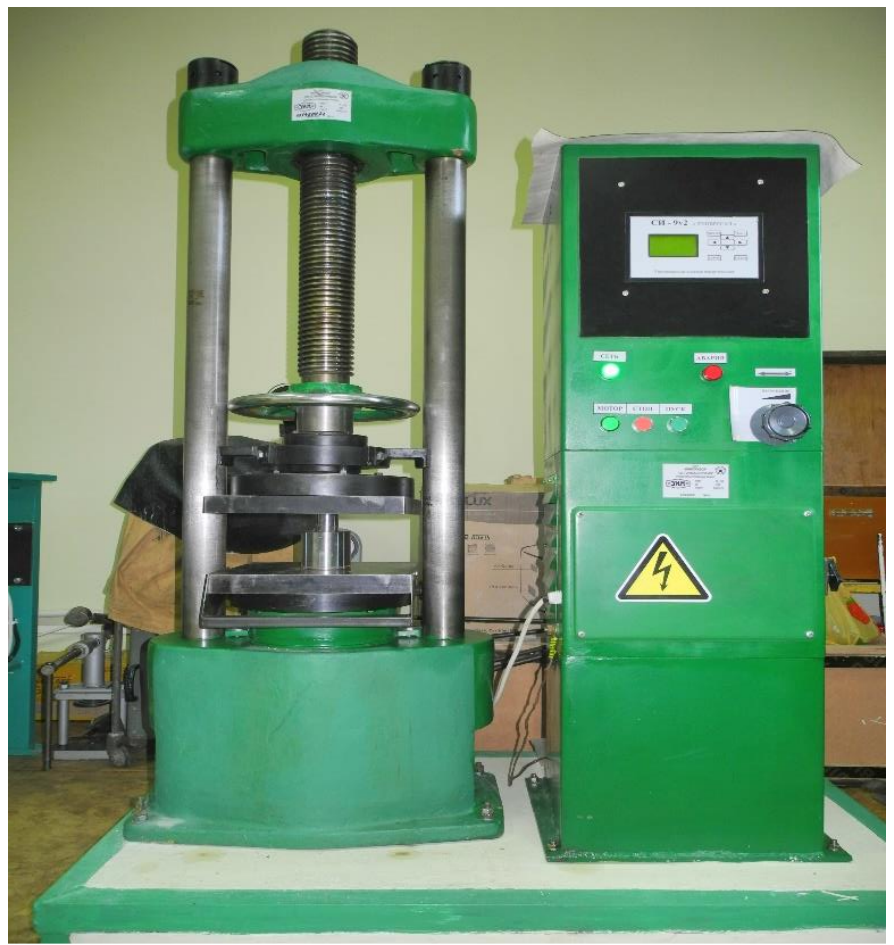

Рис. 2. Загальний вигляд гідравлічного преса П-50 для визначення деформаційних характеристик закладального матеріалу із дробленої породи

Для визначення деформаційних характеристик закладального масиву використовували експериментальні зразки, які розміщували між паралельними плитами преса. Після цього до зразків прикладалася вертикальна сила $F(\mathrm{H})$. Фото експериментальних зразків представлено на рисунку 3.

Для визначення компресійних властивостей закладального матеріалу використовували сталевий циліндр, який наповнювали подрібненою породою певної фракції, і плунжер (рис. 3, a). Діаметр циліндра $d_{u}=0,075$ м, висота циліндра $h_{u}=0,075$ м. Дослідження деформаційних характеристик закладального матеріалу з можливістю бічного розширення здійснювалося на експериментальних зразках із дробленої породи різного гранулометричного складу. Вихідний матеріал поміщали в тканинну оболонку (рис. $3, \sigma)$. Розміри зразка $b$ - ширина, м; $a$ - довжина, м; $h$ - висота, м. Геометричні розміри експериментальних зразків до проведення випробувань вказано в таблиці 3 .

Геометричні розміри експериментальних зразків до стиснення

\begin{tabular}{|c|c|c|c|c|}
\hline \multirow{2}{*}{ Зразок } & \multirow{2}{*}{ Розмір фракції, мм } & \multicolumn{3}{|c|}{ Геометричні розміри, м } \\
\cline { 2 - 4 } & & $b, \mathrm{M}$ & $a, \mathrm{M}$ & $h, \mathrm{M}$ \\
\hline 1 & $0,1-5$ & 0,168 & 0,172 & 0,04 \\
\hline 2 & $4-5$ & 0,162 & 0,169 & 0,04 \\
\hline 3 & $3-4$ & 0,165 & 0,161 & 0,04 \\
\hline 4 & $2-3$ & 0,168 & 0,171 & 0,04 \\
\hline 5 & $1-2$ & 0,172 & 0,166 & 0,04 \\
\hline 6 & $0,1-1$ & 0,171 & 0,175 & 0,04 \\
\hline
\end{tabular}




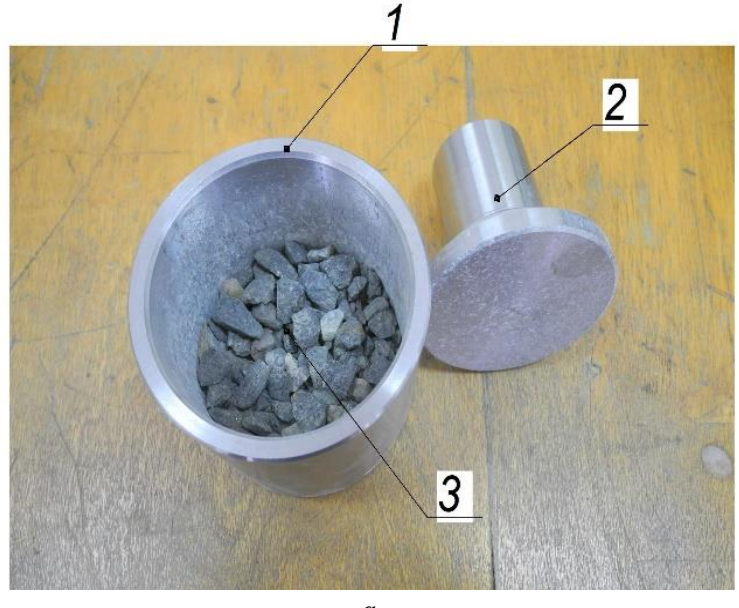

$a$

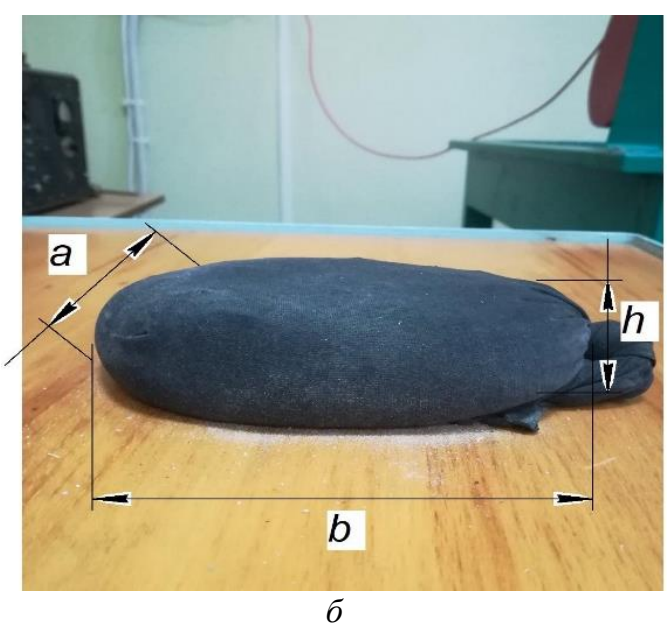

$\sigma$

Рис. 3. Експериментальні моделі для дослідження деформачійних характеристик закладальних масивів під час компресійного стиснення (а) і з можливістю бічного розширення (б): 1 - сталевий илиліндр; 2 - плунжер; 3 - подрібнена порода; 4 - тканинна оболонка з роздробленої породою

Відносну деформацію $\lambda$ експериментальних зразків за одновісного стиснення, визначали за виразом [11-13]:

$$
\lambda=\frac{\Delta h}{h}
$$

де $\Delta h$ - зміна висоти експериментального зразка, м;

$h$ - початкова висота зразка, м.

Жорсткість $C(\mathrm{H} / \mathrm{м})$ закладального масиву визначалася, зважаючи на закон Гука [14-16], за формулою:

$$
C=\frac{F}{\Delta h},
$$

де $F$ - величина стискаючої сили, Н.

Для визначення значення коефіцієнта Пуассона $(v)$ закладальних масивів із дробленої породи, які мають можливість бічного розширення, розглянемо розрахункову схему, зображену на рисунку 4.

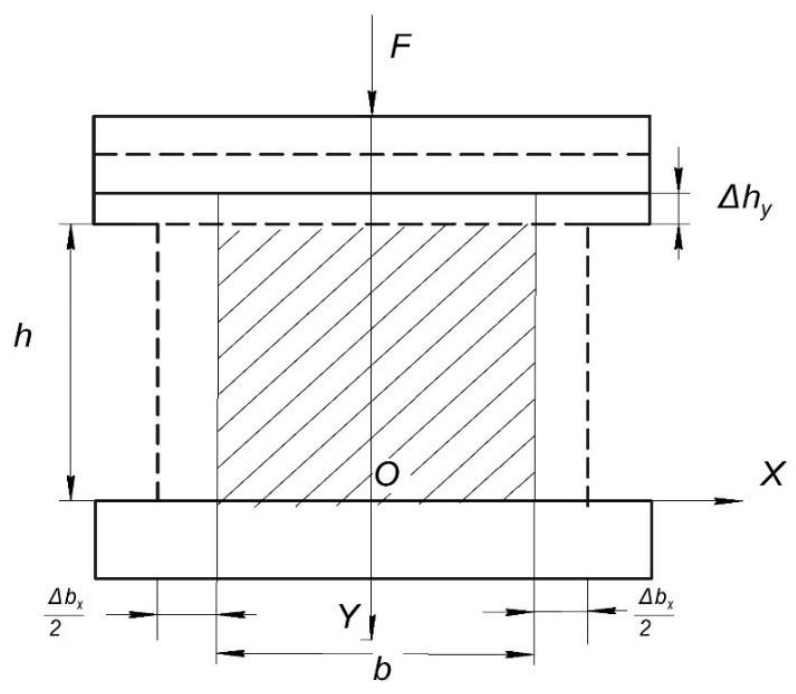

Рис. 4. Розрахункова схема для визначення коефіцієнта Пуассона v експериментального зразка із дробленої породи: $h$ - висота зразка, м; $b$ - иирина зразка, м; $\Delta h_{y}-$ зміна висоти зразка по осі OY, $\mathrm{M}$; $\Delta b_{x}=\Delta b_{x} / 2+\Delta b_{x} / 2-$ зміна ширини зразка по осі $O X, м ; F-$ стискувальна сила, $H$

За одновісного стиснення в результаті дії сили $F(\mathrm{H})$ в умовах вільного бічного розширення експериментальний зразок стискається по осі ОY і розширюється в боки по осі ОХ. В умовах вільного бічного розширення відносні поздовжні деформації можна визначити за формулою:

$$
\lambda_{y}=\frac{\Delta h_{y}}{h} .
$$


Відносні поперечні деформації визначаються як:

$$
\lambda_{x}=\frac{\Delta b_{x}}{b}
$$

3 урахуванням формул (5) і (6) коефіцієнт Пуассона дорівнює:

$$
v=\frac{\lambda_{x}}{\lambda_{y}} .
$$

Для визначення коефіцієнта ущільнення $k_{y щ}$ закладального матеріалу використовували дроблену породу, яка складалася з неоднорідних фракцій, і розсіяний на стандартні фракції матеріал. Коефіцієнт ущільнення $k_{y щ}$ дробленої породи обчислювався як відношення об'єму, який займав вихідний матеріал до ущільнення $V_{н}\left(\mathrm{M}^{3}\right)$ до об'єму, який він займає після ущільнення [17]. Тобто:

$$
k_{y u}=\frac{V_{H}}{V_{K}} .
$$

3 огляду на це, об’ємну усадку $\Delta Z(\%)$ закладального матеріалу визначали як:

$$
\Delta Z=\left(1-\frac{V_{K}}{V_{H}}\right) \cdot 100 \cdot
$$

Результати досліджень деформаційних характеристик закладальних масивів. Досліджуємо компресійне стиснення закладального матеріалу. Результати випробувань представимо у вигляді діаграми стиснення, коли по осі абсцис відкладається величина зовнішньої сили $F(\mathrm{H})$, а по осі ординат - висота зразка $h($ м) (рис. 5).
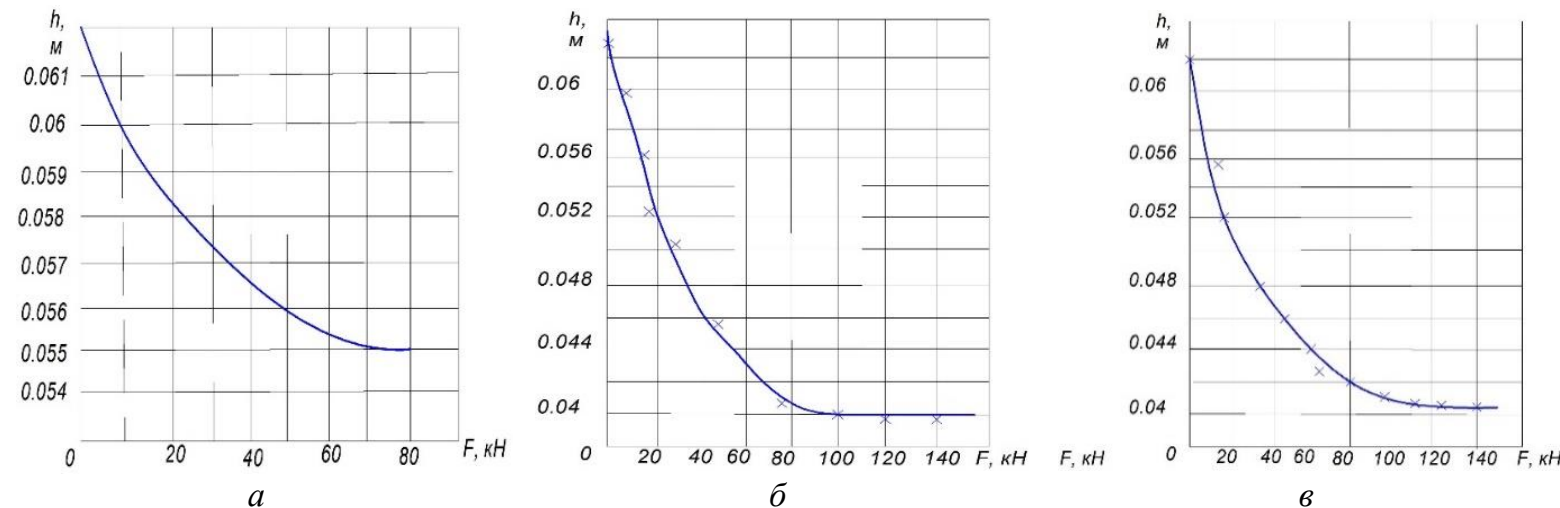

Рис. 5. Графіки змін висоти $h$ (м) експериментального зразка від величини стискаючої сили $F(\kappa H)$ під час компресійного стиснення закладального матеріалу із дробленої породи різної фракції: a-розмір фракиії 0,1-1 мм; б-розмір фракиії 0,1-5 мм; в - розмір фракції 4-5 мм

3 рисунка 5 видно, що діаграма стиснення закладального матеріалу криволінійна протягом усього графіка. Однак у деякому обмеженому інтервалі стискувального навантаження, закладальний масив все ж можна розглядати як лінійно деформоване тіло. Тому вважаємо компресію закладального масиву окремим випадком трьохосьового стиснення лінійно-деформованого тіла, коли відбувається ущільнення дробленої породи [9]. У таблиці 4 вказано дані лабораторних досліджень компресійних характеристик закладального

\begin{tabular}{|c|c|c|c|c|c|c|c|}
\hline $\begin{array}{l}\text { oै } \\
\tilde{\Xi} \\
\text { ले }\end{array}$ & $\begin{array}{c}\text { Розмір фракції, } \\
\text { мм }\end{array}$ & $\begin{array}{c}\text { Максимальна } \\
\text { стискувальна сила, } \\
F, \text { кН }\end{array}$ & $\rho_{H}, \kappa \Gamma / \mathbf{M}^{3}$ & $h, \mathrm{м}$ & $\Delta h, \mathrm{M}$ & $\lambda_{z}$ & $C, \mathrm{H} / \mathrm{M}$ \\
\hline 1 & $0,1-5$ & 150 & 1820 & 0,063 & 0,023 & 0,36 & $6,5 \cdot 10^{6}$ \\
\hline 2 & $4-5$ & 130 & 1680 & 0,062 & 0,021 & 0,33 & $6,2 \cdot 10^{6}$ \\
\hline 3 & $3-4$ & 120 & 1720 & 0,063 & 0,02 & 0,31 & $6,0 \cdot 10^{6}$ \\
\hline 4 & $2-3$ & 110 & 1860 & 0,064 & 0,017 & 0,26 & $6,4 \cdot 10^{6}$ \\
\hline 5 & $1-2$ & 90 & 1880 & 0,062 & 0,011 & 0,17 & $8,1 \cdot 10^{6}$ \\
\hline 6 & $0,1-1$ & 70 & 1940 & 0,062 & 0,007 & 0,11 & $10 \cdot 10^{6}$ \\
\hline
\end{tabular}
масиву із дробленої породи різних фракцій.

Таблиия 4 Дані лабораторних досліджень компресійних характеристик закладального масиву із дробленої породи 
На рисунку 6 наведено графік залежності відносної деформації $\lambda$ експериментального зразка під час

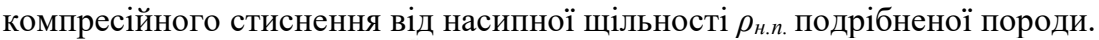

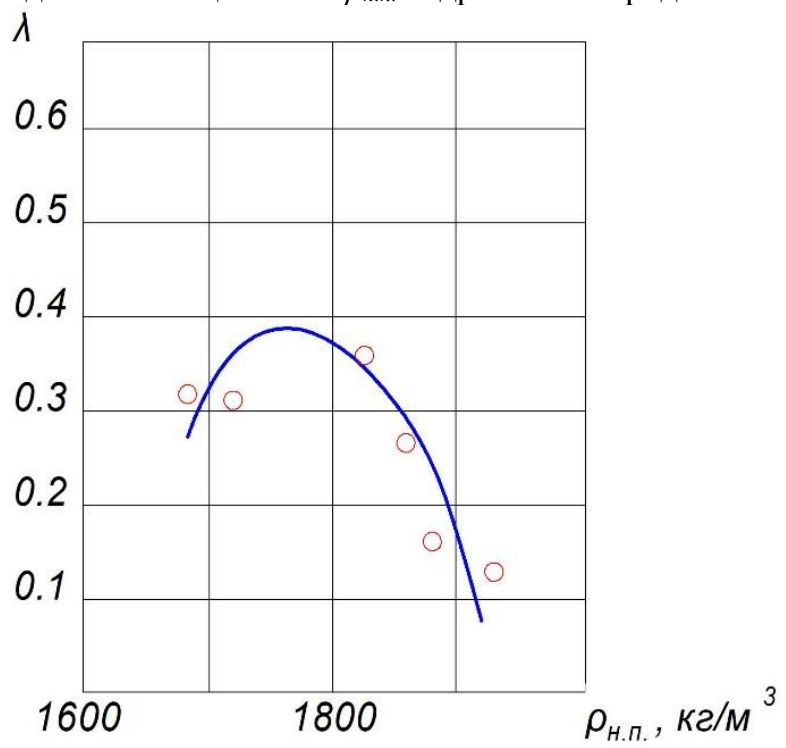

Рис. 6. Графік зміни відносної деформачії $\lambda$ закладального матеріалу під час компресійного стиснення

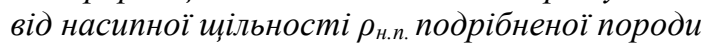

В результаті обробки експериментальних даних зміну відносної деформації $\lambda$ експериментального зразка зі збільшенням насипної щільності $\rho_{\text {н.n. }}\left(\kappa \Gamma / \mathrm{M}^{3}\right)$ дробленої породи можна описати випуклою вгору квадратичною залежністю. При цьому за максимальної насипної щільності $\rho=1940$ кг $/ \mathrm{M}^{3}$ встановлено мінімальне значення $\lambda=0,11$, а максимальні значення $\lambda$ відповідають насипній щільності в діапазоні $1750-1830 \mathrm{\kappa г} / \mathrm{M}^{3}$ (рис. 6).

На рисунку 7 представлено графік зміни жорсткості $C$ (Н/м) закладального матеріалу під час компресійного стиснення від насипної щільності $\rho_{\text {н.n. }}\left(\kappa г / \mathrm{M}^{3}\right)$ дробленої породи.

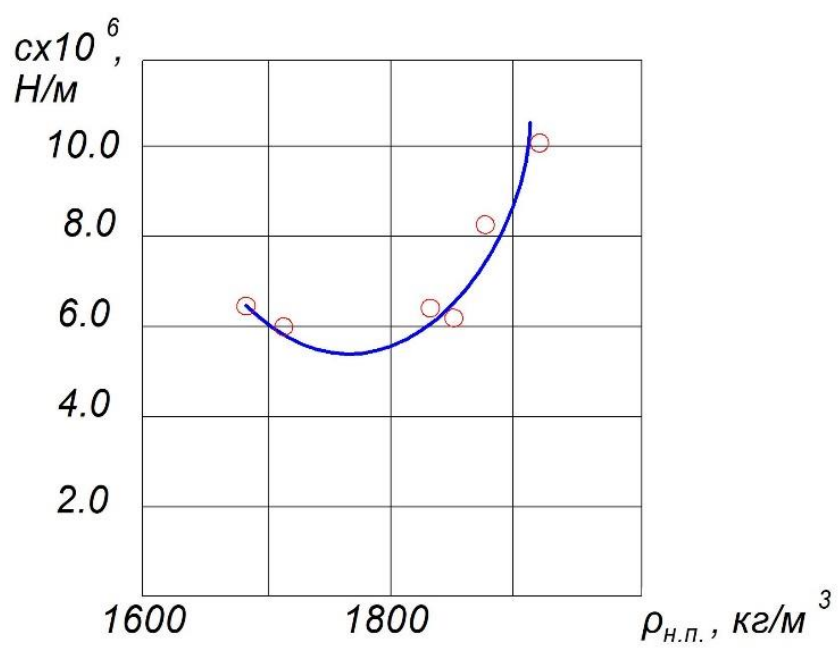

Рис. 7. Графік зміни жорсткості С (H/м) закладального матеріалу під час компресійного стиснення від насипної щульності $\rho_{\text {н.n. }}\left(\kappa 2 / \mathrm{M}^{3}\right)$ дробленої породи

3 отриманої залежності, яка також має квадратичну форму, видно, що значення жорсткості $C$ спочатку

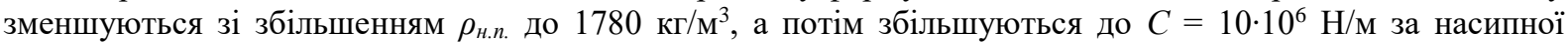
щільності дробленої породи $\rho_{\text {н.n. }}=1940$ кг $/ \mathrm{M}^{3}$ (рис. 7).

Досліджуємо поведінку закладального матеріалу за одновісного стиснення з можливістю бічного розширення дробленої породи. Геометричні розміри експериментальних зразків до і після одновісного стиснення наведено в таблиці 5.

Результати випробувань представлено як діаграму стиснення (рис. 8). 
Геометричні розміри експериментальних зразків після одновісного стиснення

\begin{tabular}{|c|c|c|c|c|c|c|c|}
\hline \multirow{2}{*}{ Зразок } & \multirow{2}{*}{$\begin{array}{c}\text { Розмір } \\
\text { фракції, мм }\end{array}$} & \multicolumn{7}{|c|}{ Геометричні розміри } \\
\cline { 3 - 8 } & $0,1-5$ & 0,192 & 0,024 & 0,219 & 0,047 & 0,0176 & 0,0224 \\
\hline 1 & $4-5$ & 0,192 & 0,03 & 0,262 & 0,093 & 0,0147 & 0,0253 \\
\hline 2 & $3-4$ & 0,192 & 0,027 & 0,241 & 0,08 & 0,0164 & 0,0236 \\
\hline 3 & $2-3$ & 0,193 & 0,025 & 0,221 & 0,05 & 0,0196 & 0,0204 \\
\hline 4 & $1-2$ & 0,192 & 0,02 & 0,191 & 0,025 & 0,0248 & 0,0152 \\
\hline 5 & $0,1-1$ & 0,19 & 0,019 & 0,195 & 0,02 & 0,0264 & 0,0136 \\
\hline 6 & \multicolumn{7}{|c}{}
\end{tabular}
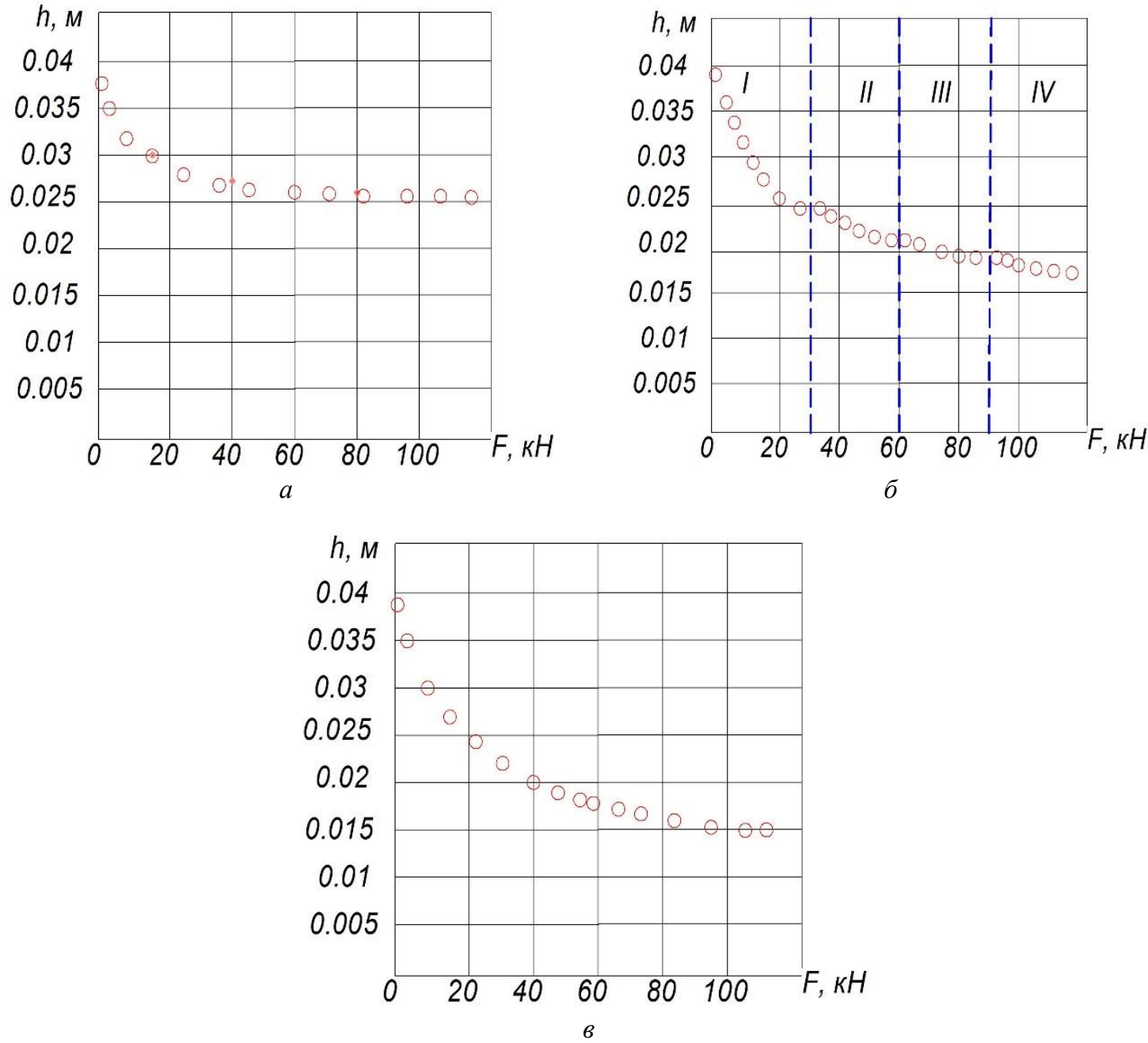

Рис. 8. Графіки зміни висоти h (м) експериментального зразка з ростом величини стискаючої сили $F(\kappa H)$ за можливості бічного розширення закладального матеріалу із дробленої породи різних фракцій: a-розмір фракиії 0,1-1 мм; б-розмір фракції 0,1-5 мм; в-розмір фракиї 4-5 мм; I, II, III і IV-етапи ущільнення закладального матеріалу

3 рисунка 8 видно, що діаграма стиснення закладального матеріалу з можливістю бічного розширення дробленої породи має криволінійну залежність, характерну для показникової функції 3 основою степеня < 1. Причому під час стиснення експериментальних зразків, представлених дрібною $(0,1-1$ мм) i великою (4-5 мм) фракціями вихідного матеріалу, зміна висоти зразка $\Delta h$ (м) відбувається плавно (рис. $8 a, b), з$ асимптотичним наближенням до деякого кінцевого значення висоти зразка. Під час стиснення зразка, представленого різними фракціями дробленої породи у вихідному матеріалі, простежується поетапне ущільнення, пов'язане з переупаковкою часток дробленої породи (рис. 8,6$)$.

На рисунку 9 наведено графіки залежності відносної деформації $\lambda$ i коефіцієнта Пуассона $v$ експериментальних зразків від насипної щільності $\rho_{\text {н.n. }}\left(\kappa г / \mathbf{M}^{3}\right)$ дробленої породи, яка початково складає закладальний масив. 

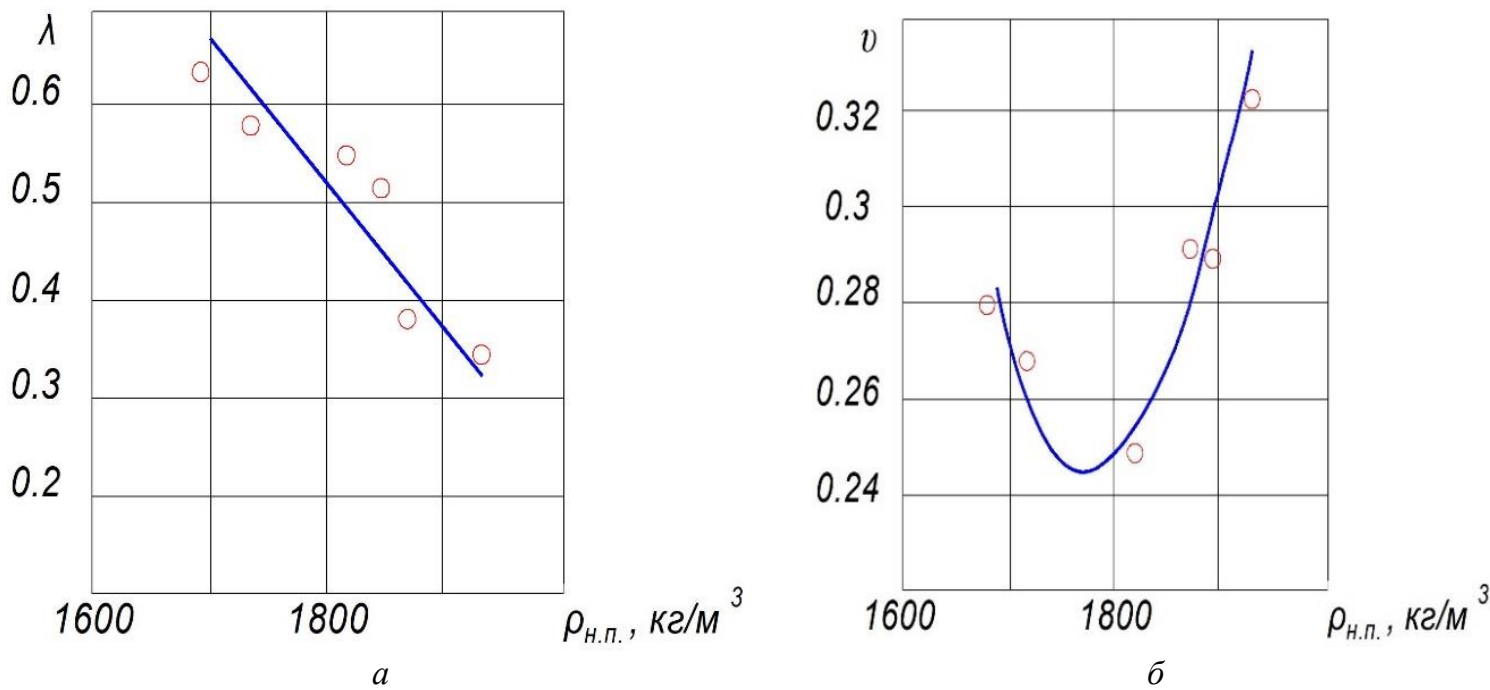

Рис. 9. Графіки залежності (а) відносної деформаџіï і(б) коефіцієнта Пуассона експериментальних

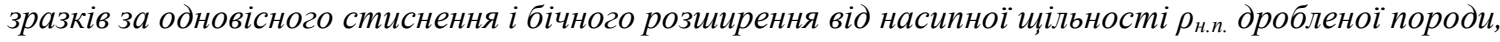
яка початково складає закладальний масив

Залежності, зображені на рисунках $9 a, 6$, побудовані за даними таблиці 6, у якій наведено результати експериментальних досліджень, отримані після одновісного стискання експериментальних зразків.

Табличя 6

Дані лабораторних досліджень визначення коефічієнта Пуассона експериментальних зразків

\begin{tabular}{|c|c|c|c|c|}
\hline Зразок & Розмір фракції, мм & $\Delta b / b$ & $\lambda=\Delta h / h$ & $v$ \\
\hline 1 & $0,1-5$ & 0,14 & 0,56 & 0,25 \\
\hline 2 & $4-5$ & 0,18 & 0,63 & 0,28 \\
\hline 3 & $3-4$ & 0,16 & 0,59 & 0,27 \\
\hline 4 & $2-3$ & 0,15 & 0,51 & 0,29 \\
\hline 5 & $1-2$ & 0,11 & 0,38 & 0,29 \\
\hline 6 & $0,1-1$ & 0,11 & 0,34 & 0,32 \\
\hline
\end{tabular}

На рисунку 9, а простежується лінійна, обернено пропорційна залежність зміни величини $\lambda$ від

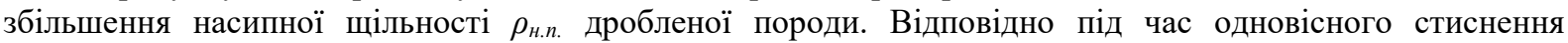
закладального матеріалу з можливістю бічного розширення значення коефіцієнта Пуассона змінюються за квадратичною залежністю, причому його мінімальні значення відповідають насипній щільності вихідного матеріалу $\rho_{\text {н.n. }}=1780-1800$ кг $/ \mathrm{M}^{3}$ (рис. 9, б).

У таблиці 7 наведено дані лабораторних досліджень визначення жорсткості $C$ (H/м) експериментальних зразків в умовах одновісного стиснення і бічного розширення ущільнюваного тіла. За даними таблиці 7 побудовано графік залежності жорсткості $C$ (Н/м) закладального матеріалу під час одновісного стиснення і бічного розширення від насипної щільності $\rho_{\text {н.n. }}\left(\right.$ кг $\left./ \mathrm{M}^{3}\right)$ дробленої породи (рис. 10).

Дані лабораторних досліджень визначення жорсткості C (H/м) експериментальних зразків

\begin{tabular}{|c|c|c|c|c|c|}
\hline Зразок & Розмір фракції, мм & $\rho_{н . n, \mathrm{\kappa} г \mathbf{M}^{3}}$ & $F$, кН & $\Delta h, \mathbf{м}$ & $C, \mathrm{H} / \mathbf{M}$ \\
\hline 1 & $0,1-5$ & 1820 & 100 & 0,022 & $4,5 \cdot 10^{6}$ \\
\hline 2 & $4-5$ & 1680 & 111 & 0,025 & $4,4 \cdot 10^{6}$ \\
\hline 3 & $3-4$ & 1720 & 110 & 0,023 & $4,7 \cdot 10^{6}$ \\
\hline 4 & $2-3$ & 1860 & 108 & 0,02 & $5,4 \cdot 10^{6}$ \\
\hline 5 & $1-2$ & 1880 & 106 & 0,015 & $7 \cdot 10^{6}$ \\
\hline 6 & $0,1-1$ & 1940 & 105 & 0,013 & $8 \cdot 10^{6}$ \\
\hline
\end{tabular}

На рисунку 10 видно, що мінімальні значення жорсткості, коли $C \approx 4,0 \cdot 10^{6} \mathrm{H} / \mathrm{M}$, забезпечуються за

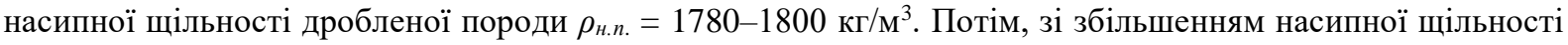


до $\rho_{\text {н.п. }}=1940$ кг $/ \mathrm{M}^{3}$, жорсткість збільшується до $\mathrm{C}=8,0 \cdot 10^{6} \mathrm{H} / \mathrm{M}$. При зменшенні насипної щільності до

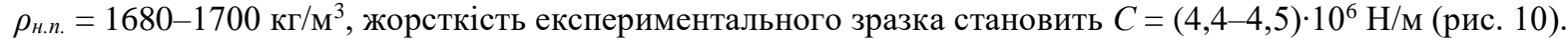

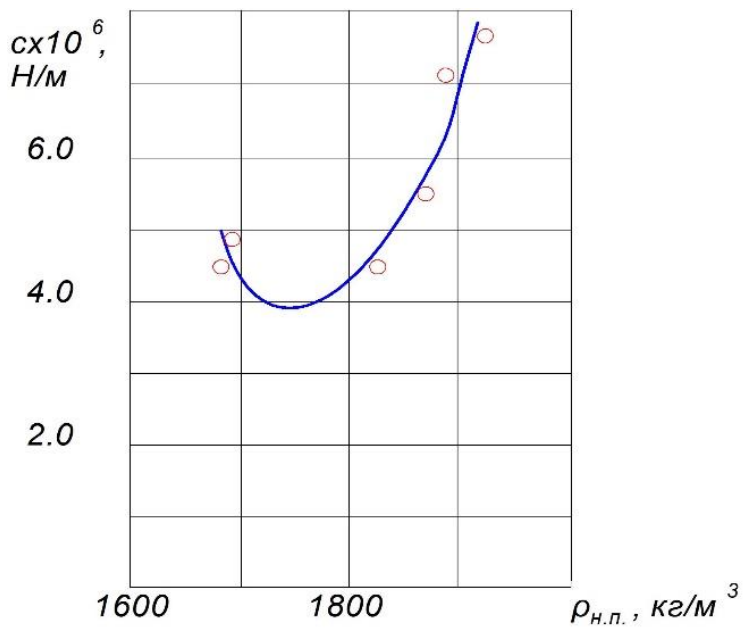

Рис. 10. Графік зміни жорсткості С закладального матеріалу за одновісного стиснення з можливістю бічного розширення від насипної щчільності $\rho_{\text {н.n. }}$ дробленої породи

Для того, щоб зіставити деформаційні характеристики закладальних масивів, основні дані зведемо в таблиці 8 і 9.

Таблиия 8

Дані лабораторних досліджень визначення деформаційних характеристик компресійного стиснення експериментальних зразків

\begin{tabular}{|c|c|c|c|c|c|}
\hline Зразок & Розмір фракції, мм & $V_{H}, \mathrm{M}^{3}$ & $V_{K}, \mathrm{M}^{3}$ & $k_{y щ}$ & $\Delta Z, \%$ \\
\hline 1 & $0,1-5$ & 0,000088 & 0,000056 & 1,57 & 37 \\
\hline 2 & $4-5$ & 0,000086 & 0,000057 & 1,51 & 34 \\
\hline 3 & $3-4$ & 0,000088 & 0,00006 & 1,46 & 32 \\
\hline 4 & $2-3$ & 0,000089 & 0,000065 & 1,36 & 27 \\
\hline 5 & $1-2$ & 0,000086 & 0,000071 & 1,21 & 18 \\
\hline 6 & $0,1-1$ & 0,000086 & 0,000077 & 1,11 & 10 \\
\hline
\end{tabular}

Таблиия 9

Дані лабораторних досліджень визначення деформаційних характеристик експериментальних зразків за одновісного стиснення з можливістю бічного розширення

\begin{tabular}{|c|c|c|c|c|c|}
\hline Зразок & Розмір фракції, мм & $V_{H}, \mathrm{M}^{3}$ & $V_{K}, \mathrm{M}^{3}$ & $k_{y щ}$ & $\Delta Z, \%$ \\
\hline 1 & $0,1-5$ & 0,00115 & 0,00074 & 1,55 & 36 \\
\hline 2 & $4-5$ & 0,00109 & 0,000739 & 1,47 & 32 \\
\hline 3 & $3-4$ & 0,00106 & 0,000758 & 1,39 & 29 \\
\hline 4 & $2-3$ & 0,00114 & 0,000838 & 1,36 & 27 \\
\hline 5 & $1-2$ & 0,00114 & 0,000909 & 1,25 & 20 \\
\hline 6 & $0,1-1$ & 0,00119 & 0,000978 & 1,21 & 18 \\
\hline
\end{tabular}

За отриманими експериментальними даними побудовано графіки залежності коефіцієнта ущільнення $k_{y щ}$ дробленої породи від насипної щільності $\rho_{\text {н.n. }}\left(\kappa г / \mathrm{m}^{3}\right)$ вихідного матеріалу (рис. 11).

3 рисунків $11 a$, б видно, що значення коефіцієнта ущільнення дробленої породи пов'язані 3 гранулометричним складом вихідного матеріалу випуклою вгору квадратичною залежністю.

Розглядаючи за експериментальними даними таблиць 8 і 9 об'ємну усадку дробленої породи (рис. 12), можна зробити висновок, що за умови неоднорідного гранулометричного складу значення об'ємної усадки не перевищують $\Delta Z=36-37 \%$ (рис. $12 a, \sigma)$. Для закладального матеріалу з однаковою фракцією об'ємна усадка зменшується і за $\rho_{\text {н.n. }}=1680$ кг $/ \mathrm{m}^{3}$ становить $\Delta Z=32-34 \%$ для фракції 4-5 мм та $\Delta Z=10-18 \%$ для фракції 0,1-1 мм. Якщо насипна щільність $\rho_{\text {н.n. }}=1940$ кг $/ \mathrm{M}^{3}$, то об'ємна усадка становить $\Delta Z=10 \%$ за компресійного стиснення (рис. $12, a)$ i $\Delta Z=18 \%$ за одновісного стиснення 3 можливістю бічного розширення дробленої породи (рис. $12, \sigma)$. 

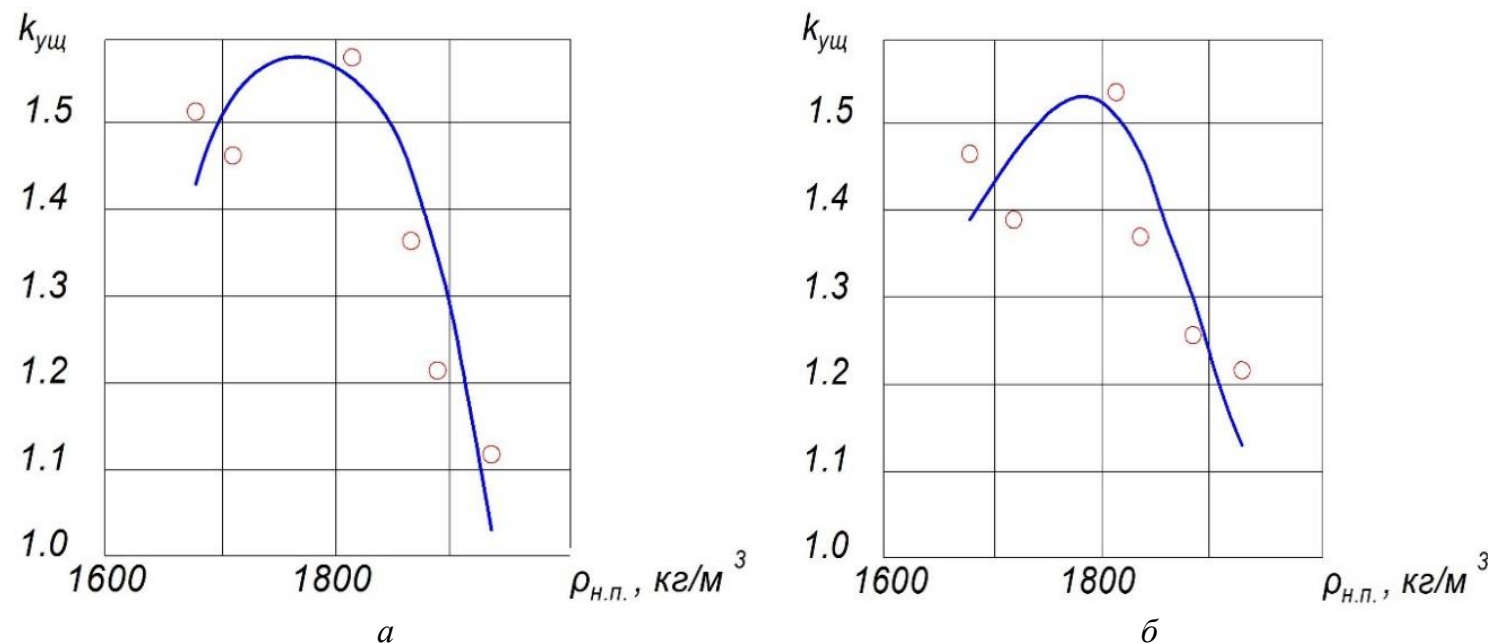

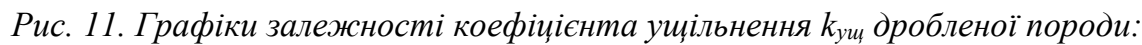
$a$ - за компресійного стиснення $і$ б - одновісного стиснення з можливістю бічного розширення від насипної щүільності $\rho_{\text {н.п. }}\left(\kappa 2 / \mathrm{M}^{3}\right)$ вихідного матеріалу
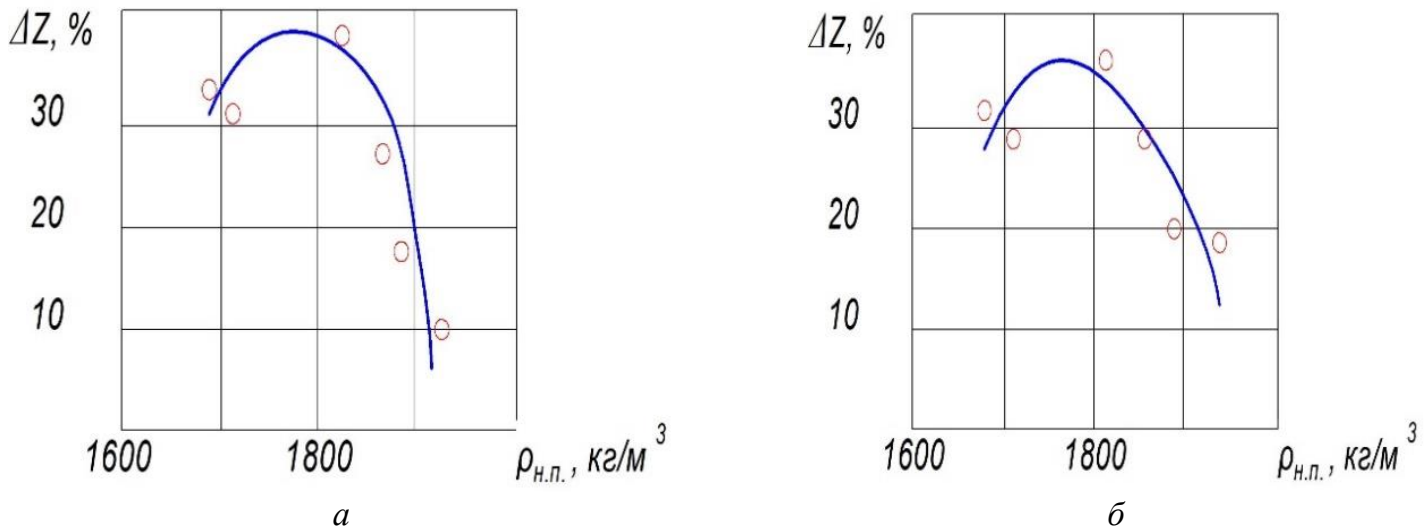

Рис. 12. Графіки залежності об'ємної усадки $\Delta Z$ (\%) експериментальних зразків із дробленої породи за: $a$-компресійного стиснення $і$ б-одновісного стиснення з можливістю бічного розширення від насипної щиільності $\rho_{\text {н.n. }}\left(\kappa 2 / \mathrm{M}^{3}\right)$ вихідного матеріалу

У таблиці 10 вказано зведені дані експериментальних досліджень деформаційних характеристик закладальних масивів.

Таблиия 10

Дані експериментальних досліджень деформаційних характеристик закладальних масивів

\begin{tabular}{|c|c|c|c|c|c|c|c|}
\hline \multirow{3}{*}{ Зразок } & \multirow{2}{*}{$\begin{array}{c}\text { Розмір } \\
\text { фракції, мм }\end{array}$} & \multicolumn{6}{|c|}{ Закладальний масив в умовах } \\
\cline { 3 - 8 } & & $k_{y щ}$ & $\lambda$ & $\Delta Z, \%$ & $k_{y щ}$ & \multicolumn{3}{c|}{ бічного розширення } \\
\cline { 3 - 8 } & $0,1-5$ & 1,57 & 0,36 & 37 & 1,55 & 0,56 & 36 \\
\hline 1 & $4-5$ & 1,51 & 0,33 & 34 & 1,47 & 0,63 & 32 \\
\hline 2 & $3-4$ & 1,46 & 0,31 & 32 & 1,39 & 0,59 & 29 \\
\hline 3 & $2-3$ & 1,36 & 0,26 & 27 & 1,36 & 0,51 & 27 \\
\hline 4 & $1-2$ & 1,21 & 0,17 & 18 & 1,25 & 0,38 & 20 \\
\hline 5 & $0,1-1$ & 1,11 & 0,11 & 10 & 1,21 & 0,34 & 18 \\
\hline 6 & & \multicolumn{3}{|c|}{}
\end{tabular}

Під час проведення дослідів було зафіксовано, що експериментальні зразки, які піддавалися одновісному стисненню, мають максимальну піддатливість, коли представлені неоднорідним гранулометричним складом у вихідному матеріалі використовуваної дробленої породи. 3 огляду на це, було виконано порівняння деформаційних характеристик експериментальних зразків однакового фракційного складу, які піддавалися компресійному стисненню і одновісному стисненню з боковим розширенням. Для таких зразків була встановлена величина жорсткості $C(\mathrm{H} / \mathrm{M})$ і відносної деформації $\lambda$ стискуваного тіла. 
На рисунку 13 наведено графіки залежності жорсткості $C$ (H/м) закладального матеріалу із дробленої породи, розмір фракції якої 0,1-5 мм від відносної деформації $\lambda$.

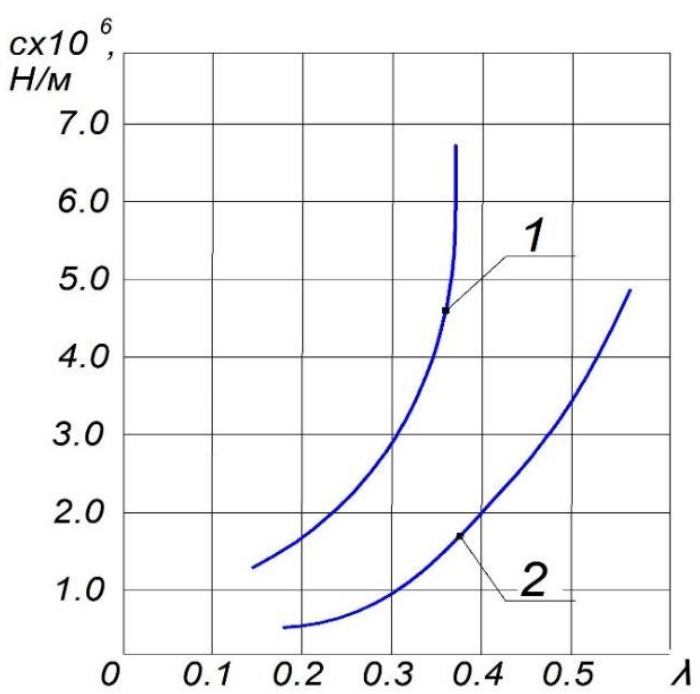

Рис. 13. Графіки залежності жорсткості С (H/м) закладального матеріалу із дробленої породи (розмір фракції 0,1-5 мм) від його відносної деформації: 1 - за компресійного стиснення; 2 - за одновісного стиснення з можливістю бічного розширення

3 наведених залежностей видно, що зі збільшенням $\lambda$, значення жорсткості експериментальних зразків $C$ (Н/м) збільшується. Встановлено, що під час деформації зразків на 20 \% значення їх жорсткості за компресійного стиснення дорівнює $C=1,7 \cdot 10^{6} \mathrm{H} / \mathrm{M}$, а за одновісного стиснення 3 можливістю бічного розширення $C=0,45 \cdot 10^{6} \mathrm{H} / \mathrm{M}$. Зі збільшенням відносної деформації до значень $\lambda=0,36$ величина жорсткості за компресійного стиснення збільшується до $C=7,0 \cdot 10^{6} \mathrm{H} / \mathrm{M}$, а за одновісного стиснення 3 бічним розширенням до $C=1,7 \cdot 10^{6} \mathrm{H} / \mathrm{м}$ (рис. 13 ).

Слід зазначити, що встановлені з дослідів деформаційні характеристики дають оцінку реальним властивостям закладальних масивів з певною похибкою, яка неминуче пов'язана з наявністю масштабного ефекту. Оцінка цього ефекту вимагає проведення додаткових досліджень.

Обговорення результатів експериментальних досліджень деформаційних характеристик закладальних масивів. У результаті виконаних досліджень визначено деформаційні характеристики матеріалу, який моделює закладальний масив із дробленої породи, призначений для зменшення рівня просідання земної поверхні, охорони будівель і споруд, охорони гірничих виробок та для підтримання бічних порід у виробленому просторі виїмкової дільниці вугільної шахти. Деформаційні характеристики $\epsilon$ найбільш важливими фізико-механічними властивостями, використання яких дозволить сформулювати вимоги, що ставляться до закладальних масивів різного призначення. Деформаційні характеристики оцінювалися в лабораторних умовах на експериментальних зразках, які піддалися компресійному стисненню (рис. $1 ; 3, a)$ і одновісному стисненню з можливістю бічного розширення ущільнюваного тіла (рис. 1; 3, б). Як показники, які характеризують здатність закладальних масивів змінювати розміри під дією зовнішньої сили, використовували величину відносної деформації $\lambda(1)$, коефіцієнт Пуассона $v(5)$, коефіцієнт ущільнення подрібненої породи $k_{y щ}(6)$ і об'ємну усадку $\Delta Z(\%)$ закладального масиву (7).

Експериментально встановлено, що за одновісного стиснення дробленої породи з можливістю бічного розширення закладального матеріалу величина відносної деформації ущільнюваного тіла змінюється за лінійною залежністю (рис. 9, а). Причому максимальні значення цієї величини $\lambda=0,68$ зафіксовані за мінімальних значень насипної щільності вихідного матеріалу, коли $\rho_{\text {н.n. }}=1700$ кг $/ \mathrm{m}^{3}$. Мінімальні значення

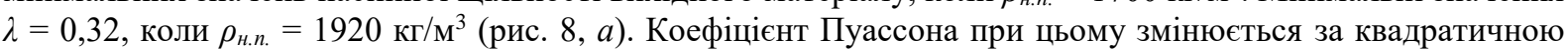
залежністю (рис. 9, б). Максимальні значення досліджуваного коефіцієнта забезпечуються після стиснення вихідного матеріалу великої або дрібної фракції, що напочатку складає закладальний масив. Насипна

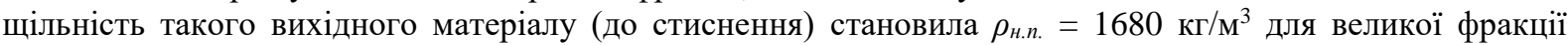
(розмір 4-5 мм) і $\rho_{\text {н.n. }}=1920-1940$ кг/м³ для дрібної фракції (розмір 0,1-1 мм). Мінімальні значення коефіцієнта Пуассона зафіксовані за одновісного стиснення дробленої породи, представленої неоднорідним гранулометричним складом (фракція 0,1-5 мм) (рис. 9, б). За умови неоднорідного гранулометричного складу дробленої породи, коли насипна щільність вихідного закладального матеріалу становить $\rho_{\text {н.n. }}=1780-1820 \kappa \mathrm{m}^{3}$, за одновісного стиснення відбувається взаємне зміщення фракцій (рис. 7,6$)$, в результаті чого досягається максимальні коефіцієнт ущільнення $\left(k_{y}=1,55-1,57\right)$ дробленої породи (рис. 11, табл. 10) і об’ємна усадка $(\Delta Z=36-37$ \%) (рис. 12, табл. 10$)$. 
Таким чином, в результаті виконаних досліджень встановлено, що за одновісного стиснення неоднорідної (за розміром частинок) дробленої породи (розмір фракцій 0,1-5 мм) відносна деформація експериментального зразка, що зафіксована в сталевому циліндрі $(\lambda=0,36)$, менша за відносну деформацію такого ж зразка, якщо можливе розширення закладального матеріалу $(\lambda=0,56)$ (табл. 10$)$. Маючи за одновісного стиснення однакову об'ємну усадку $(\Delta Z=36-37 \%)$, в умовах, коли розширення ущільнюваного тіла неможливе, зменшення об'єму відбувається за рахунок перепакування частинок породи різних фракцій і зменшення пустотності. В умовах, коли закладальний матеріал має можливість бічного розширення, зменшення об'єму відбувається за рахунок перепакування та розповзання подрібненої породи під дією навантаження. При цьому, чим більш неоднорідною є порода, тим ефективніший процес перепакування. Практично за однакових значень коефіцієнта ущільнення подрібненої породи $k_{y m} \approx 1,55-$ 1,57 величина відносної деформації в умовах одновісного стиснення в сталевому циліндрі на $36 \%$ менше, ніж у разі ущільнення закладального матеріалу з можливістю його бічного розширення.

Враховуючи, що закладка виробленого простору застосовується 3 різними цілями, вимоги до закладального матеріалу ставлять різні. Для запобігання осіданню земної поверхні, охорони виробок, будівель і споруд, крім неоднорідності гранулометричного складу вихідного матеріалу, закладальний масив має формуватися в умовах обмеження можливості бічного розширення, що дозволить обмежити зміщення бічних порід у вуглепородному масиві під час розвантаження від напружень. У випадках, коли закладка виробленого простору використовується як спосіб захисту навколишнього середовища від техногенного впливу підземних гірничих робіт, допустиме бічне розширення ущільнюваного закладального масиву.

Висновок. Деформаційні характеристики закладальних масивів із дробленої породи визначають здатність системи відкликатися на вплив зовнішніх чинників, які проявляються у вуглепородній товщі, що вміщує виробки, під час розвантаження від напружень. Мінімізувати шкідливі прояви гірничого тиску у виробках можливо за дотримання певних вимог, що ставляться до закладальних масивів. Вимоги до властивостей закладальних масивів можуть бути різними і залежать від їх призначення. Максимальний ефект від застосування закладки виробленого простору як способу запобігання осіданню земної поверхні, охорони виробок, будівель і споруд забезпечується використанням неоднорідного за фракційним складом вихідного матеріалу і створенням умов, що обмежують бічне розширення. При цьому досягаються характеристики жорсткості закладального масиву, що дозволяють йому виконувати роль стійких піддатливих опор, які мають достатню тримкість, що робить можливим плавний прогин бічних порід у виробленому просторі.

\section{Список використаної літератури:}

1. Experimental studies of the seam openings competence in different methods of protection under pitch and steep coal seams development / Ya.Liashok, I.Iordanov, D.Chepiga, S.Podkopaiev // Mining of Mineral Deposits. - 2018. Vol. 12, Issue 4. - P. 9-19. DOI: 10.1547//mining 12.04.009.

2. Андрушко В.Ф. Управление кровлей в сложных горно-геологических условиях / В.Ф. Андрушко, С.А. Саратикяни, Ю.Г. Спицын. - Киев : Техника, 1985. - 128 с.

3. Зборщик М.П. Механизм повышения устойчивости кровли в лавах при применении закладки выработанного пространства / М.П. Зборшик, С.В. Подкопаев // Уголь Украины. - 1992. - № 5. - С. 20-23.

4. Жуков B.E. Об одной стратегической ошибке в разрешении проблемы разработки крутых пластов / B.E. Жуков // Уголь Украины. - 2001. - № 7. - С. 6-10.

5. Сипидин В.П. Исследование грунтов в условиях трехосного сжатия / В.П. Сипидин, Н.Н. Сидоров. - М. ; Л. : Гос. из-во по строительству, архитектуре и строит. материалам, 1963. -94 с.

6. Craing R.F. Soil Mechanics / R.F. Craing. - Spon Press, 1997. - 496 p.

7. Борщ-Компаниеи Н.И. Механика грунтов / Н.И. Борщ-Компаниец. - Омск : Из-во СибАДИ, 2009. - 106 с.

8. Лабораторный практикум по курсу «Механика горных пород» / С.В. Подкопаев, Н.Н. Гавриш, Б.М. Деглин, В.И. Каменеи. - Донецк : ДонНТУ, 2012. - 48 с.

9. Цытович Н.А. Механика грунтов / Н.А. Цытович. - М. : Высшая школа, 1983. - 288 с.

10. Цирель С.В. Оценка влияния гранулометрического состава на сжимаемость и пустотность закладочного материала / С.В. Цирель, Ю.С. Гапонов, А.Н. Шоков // Горный информационно-аналитический бюллетень. 2013. - № 12. - С. 80-83.

11. Тер-Мартиросян 3.Г. Определение прочных характеристик несвязанных грунтов при компрессионных испытаниях / 3.Г. Тер-Мартиросян, А.Ю. Мирный, М.Н. Джаро // Интернет-Вестник ВолгГАСУ. - 2012. № 3. - C. 1-6.

12. Wesley L.D. Fundamentals of Soil Mechanics for Sedimentary and Residual Soils / L.D. Wesley. - John Wiley \& Sons, Inc, 2010. $-440 \mathrm{p}$.

13. Ishibashi I. Soil Mechanics / I.Ishibashi, H.Hazarika. - CRC Press, 2015. - 420 p.

14. Мирный А.Ю. Подбор гранулометрического состава песчано-гравийных смесей для песчаных подушек и насыпей / А.Ю. Мирный, А.3. Тер-Мартиросян // Жилищное строительство. - 2014. - № 9. - С. 43-49.

15. Dependence in Probability and statistics ; P.Bertail, P.Soulier, P.Doukhan (eds.). - Berlin : Springer, 2006. -490 p.

16. Kobayashi H. Probability, Random Processes and Statistical Analysis / H.Kobayashi, B.L. Mark, W.Turin. Cambridge University Press, 2012. - 812 p.

17. Robitalle V. Mecanique des sols: Theorie et pratique / V.Robitalle, D.Tremblay. - Canada, 1997. - 341 p. 


\section{References:}

1. Liashok, Ya., Iordanov, I., Chepiga, D. and Podkopaiev, S. (2018), «Experimental studies of the seam openings competence in different methods of protection under pitch and steep coal seams development», Mining of Mineral Deposits, Vol. 12, Issue 4, pp. 9-19, doi: 10.1547//mining 12.04.009.

2. Andrushko, V.F., Saratikyants, S.A. and Spitsyn, Yu.G. (1985), Upravleniye krovley v slozhnykh gornogeologicheskikh usloviyakh, Tekhnika, Kiyev, 128 p.

3. Zborshchik, M.P. and Podkopaev, S.V. (1992), «Mekhanizm povysheniya ustoychivosti krovli v lavakh pri primenenii zakladki vyrabotannogo prostranstva», Ugol' Ukrainy, No. 5, pp. 20-23.

4. Zhukov, V.E. (2001), «Ob odnoi strategicheskoi oshibke v razreshenii problemy razrabotki krutykh plastov», Ugol' Ukrainy, No. 7, pp. 6-10.

5. Sipidin, V.P. and Sidorov, N.N. (1963), Issledovanie gruntov v usloviyakh trekhosnogo szhatiya, Gos. iz-vo po stroitel'stvu, arkhitekture i stroit. materialam, M., L., 94 p.

6. Craing, R.F. (1997), Soil Mechanics, Spon Press, 496 p.

7. Borshch-Kompaniets, N.I. (2009), Mekhanika gruntov, Iz-vo SibADI, Omsk, 106 p.

8. Podkopaev, S.V., Gavrish, N.N., Deglin, B.M. and Kamenets, V.I. (2012), Laboratornyy praktikum po kursu «Mekhanika gornykh porod», DonNTU, Donetsk, 48 p.

9. Tsytovich, N.A. (1983), Mekhanika gruntov, Vysshaya shkola, M., 288 p.

10. Tsirel', C.B., Gaponov, Yu.S. and Shokov, A.N. (2013), «Otsenka vliyaniya granulometricheskogo sostava na szhimaemost' i pustotnost' zakladochnogo materiala», Gornyi informatsionno-analiticheskii byulleten', No. 12, pp. 80-83.

11. Ter-Martirosyan, Z.G., Mirnyi, A.Yu. and Dzharo, M.N. (2012), «Opredelenie prochnykh kharakteristik nesvyazannykh gruntov pri kompressionnykh ispytaniyakh», Internet-Vestnik VolgGASU, No. 3, pp. 1-6.

12. Wesley, L.D. (2010), Fundamentals of Soil Mechanics for Sedimentary and Residual Soils, John Wiley \& Sons, Inc, 440 p.

13. Ishibashi, I. and Hazarika, H. (2015), Soil Mechanics, CRC Press, 420 p.

14. Mirnyi, A.Yu. and Ter-Martirosyan, A.Z. (2014), «Podbor granulometricheskogo sostava peschano-graviinykh smesey dlya peschanykh podushek i nasypei», Zhilishchnoye stroitel'stvo, No. 9, pp. 43-49.

15. Bertail, P., Soulier, P. and Doukhan, P. (eds.) (2006), Dependence in Probability and statistics, Springer, Berlin, 490 p.

16. Kobayashi, H., Mark, B.L. and Turin, W. (2012), Probability, Random Processes and Statistical Analysis, Cambridge University Press, $812 \mathrm{p}$.

17. Robitalle, V. and Tremblay, D. (1997), Mecanique des sols: Theorie et pratique, Canada, 341 p.

Бачурін Леонід Леонідович - кандидат технічних наук, перший проректор Донецького національного технічного університету.

Наукові інтереси: підземна розробка корисних копалин; гірництво.

https://orcid.org/0000-0003-2513-7284.

E-mail: leonid.bachurin@donntu.edu.ua.

Іорданов Ігор В'ячеславович - кандидат технічних наук Донецького національного технічного університету.

Наукові інтереси: підземна розробка корисних копалин; гірництво.

https://orcid.org/0000-0001-9991-781X.

E-mail: gendir@eme.kiev.ua

Сімонова Юлія Ігорівна - аспірант Донецького національного технічного університету.

Наукові інтереси: підземна розробка корисних копалин; гірництво.

https://orcid.org/0000-0002-9192-7850.

E-mail: yuliia.simonova@donntu.edu.ua.

Король Антон В'ячеславович - аспірант Донецького національного технічного університету.

Наукові інтереси: підземна розробка корисних копалин; гірництво.

https://orcid.org/0000-0001-6667-425X.

E-mail: akorolv2017@gmail.com.

Подкопаєв Свген Сергійович - аспірант Донецького національного технічного університету. Наукові інтереси: підземна розробка корисних копалин; гірництво. https://orcid.org/0000-0002-5010-8349.

E-mail:podkopayev96@gmail.com.

Каюн Олексій Петрович - аспірант Донецького національного технічного університету.

Наукові інтереси: підземна розробка корисних копалин; гірництво.

https://orcid.org/0000-0003-1404-6096.

E-mail: a.p.kayun@ukr.net. 